\title{
Guillaume JACQUES*
}

\section{The lateralization of labio-dorsals in Hmongic}

Abstract: This paper provides support for Ratliff's hypothesis of a highly unusual shift from labio-dorsal to lateral affricates in some Hmongic languages. It proposes that this shift, which results from a series of sound changes, constitutes evidence for positing a 'Tlowic' subgroup within Hmongic. In addition, it disproves attempts to use correspondences between Chinese labiovelars and Hmongic lateral affricates in borrowings as evidence to revise Chinese historical phonology.

Keywords: Hmongic, labiovelars, lateral affricates, merger, Old Chinese

\section{Introduction}

A few Hmongic languages, including White Hmong (hmon1333), ${ }^{2}$ Green Hmong (hmon1264), Xianjin and Shimen, ${ }^{3}$ have the lateral affricate tlor a dental stop $d$ - corresponding to words with labiovelars elsewhere in Hmong-Mien (Wang and Mao 1995: \#661; \#687). ${ }^{4}$ Some reconstructions of Hmong-Mien, including those of Wang and Mao (1995) and Ostapirat (2016), reconstruct the onset of these groups with a consonant cluster comprising a labio-dorsal (labiovelar or labio-uvular) stop followed by an *-l-. ${ }^{5}$

However, most of the words presenting this correspondence are Chinese loanwords that do not have a [stop + liquid] cluster at any stage of their known history (Ratliff 2010: 124; 126). Ratliff proposes instead a reconstruction with simple labiovelars in these sets, a solution which implicitly entails that an unusual shift from labiovelar to lateral took place in White Hmong, Xianjin and Shimen.

It is not immediately obvious which of the two alternatives is the correct one, as both raise puzzling problems: the Wang/Ostapirat hypothesis would suggest a serious revision of either Chinese historical phonology or Hmong-Mien/Chinese comparison, as it is not compatible with any of the present works on Old Chinese reconstruction, while the Ratliff hypothesis implies the existence of a very unusual sound change.

\footnotetext{
*Jacques, Guillaume, Southwest University, Chongqing, China / CNRS-CRLAOINALCO-EHESS, Paris, Email: rgyalrongskad@gmail.com

${ }^{2}$ Whenever applicable, the code in the Glottolog database (Hammarström et al. 2020) is provided for the languages cited in this work.

${ }^{3}$ Shimen is a subvariety of the Diandongbei (larg1235) subgroup of Greater Chuanqiandian (grea1295), spoken in Weining county 威宁县. Xianjin belongs to the Chuanqiandian proper subgroup (chua1248), and is spoken in Bijie 毕节市 county in Guizhou, China.

${ }^{4}$ I use to symbol \# to indicate the reference number of the cognate sets in Wang and Mao (1995).

${ }^{5}$ The Hmong-Mien data in this paper are cited from Wang and Mao (1995) and Ratliff (2010), except for Green Hmong which is from Lyman (1974). White Hmong and Jiangdi Mien (iumi1238) data have been systematically rechecked in Heimbach (1979) and Mao (1992). Middle Chinese is based on Baxter's (1992) transcription, but converted to IPA.
} 
The aim of this paper is to examine these two hypotheses in detail and evaluate whether it is possible to disprove one of the two. First, I examine all correspondences involving White Hmong $d$-, Xianjin and Shimen $t_{0}-$ and Green Hmong $k l$ - in Hmong-Mien and the proposed reconstructions for these onsets. Second, I evaluate the advantages and disadvantages of the two competing hypotheses, and argue that Ratliff's solution is preferable. Third, I show how this shift from labiodorsal to lateral affricate (via clusters of the type [velar + lateral]) is significant for Hmong-Mien reconstruction and Old Chinese historical phonology, and additionally for the panchronic typology of sound changes.

\section{The correspondences involving White Hmong $d$ - in Hmong-Mien languages}

\subsection{Hmongic correspondences}

Table 1, using data drawn from Wang and Mao (1995) and Ratliff (2010), completed with Green Hmong data from Lyman (1974) collected by the author, illustrates the attested correspondences of the lateral affricates $t_{0}-$ in Xianjin and Green Hmong, ${ }^{6}$ tl-, $d l \hbar$ - in Shimen, and the voiced stop $d$ in White Hmong (described as preglottalized $[d]$ or as fully voiced $[d]$ by different authors, see Jarkey 1987 and Niederer 1998: 93 for a summary of the references) in the rest of Hmong-Mien. ${ }^{7}$

\footnotetext{
${ }^{6}$ In Lyman's (1974) Green Hmong dictionary, the lateral affricate is transcribed as $k l-$, but the author specifies that $[k l]$ and $[t l]$ are both possible realizations of this onset, a fact confirmed by Mortensen (2004). It could in principle be either analyzed as a [stop + lateral] cluster or as a lateral affricate; the second option is favoured in this paper, but the first one would not significantly change the discussion in this work.

${ }^{7}$ For 'cross', (Ratliff 2010: 151) provides dhau 'through, pass through, beyond' as the White Hmong cognate. However, Xianjin $t l u a^{5}$, Shimen $t a^{5}$ and Green Hmong $k l a u^{5}$ are better compared to White Hmong $d u a^{5}$ 'pass on, go, surpass, more than, better than' (Heimbach 1979: 38) instead. There is little doubt that this comparison is valid: White Hmong $d u a^{5}$ is used in 'surpass' comparative constructions exactly like 過 $k w a H$ in many varieties of Chinese (Chappell and Peyraube 2015; Chiang 2017. White Hmong dhau ${ }^{5}$ should rather be compared with Green Hmong khlau ${ }^{5}$ 'exceed, over-reach, pass' with an aspirated lateral affricate.
} 


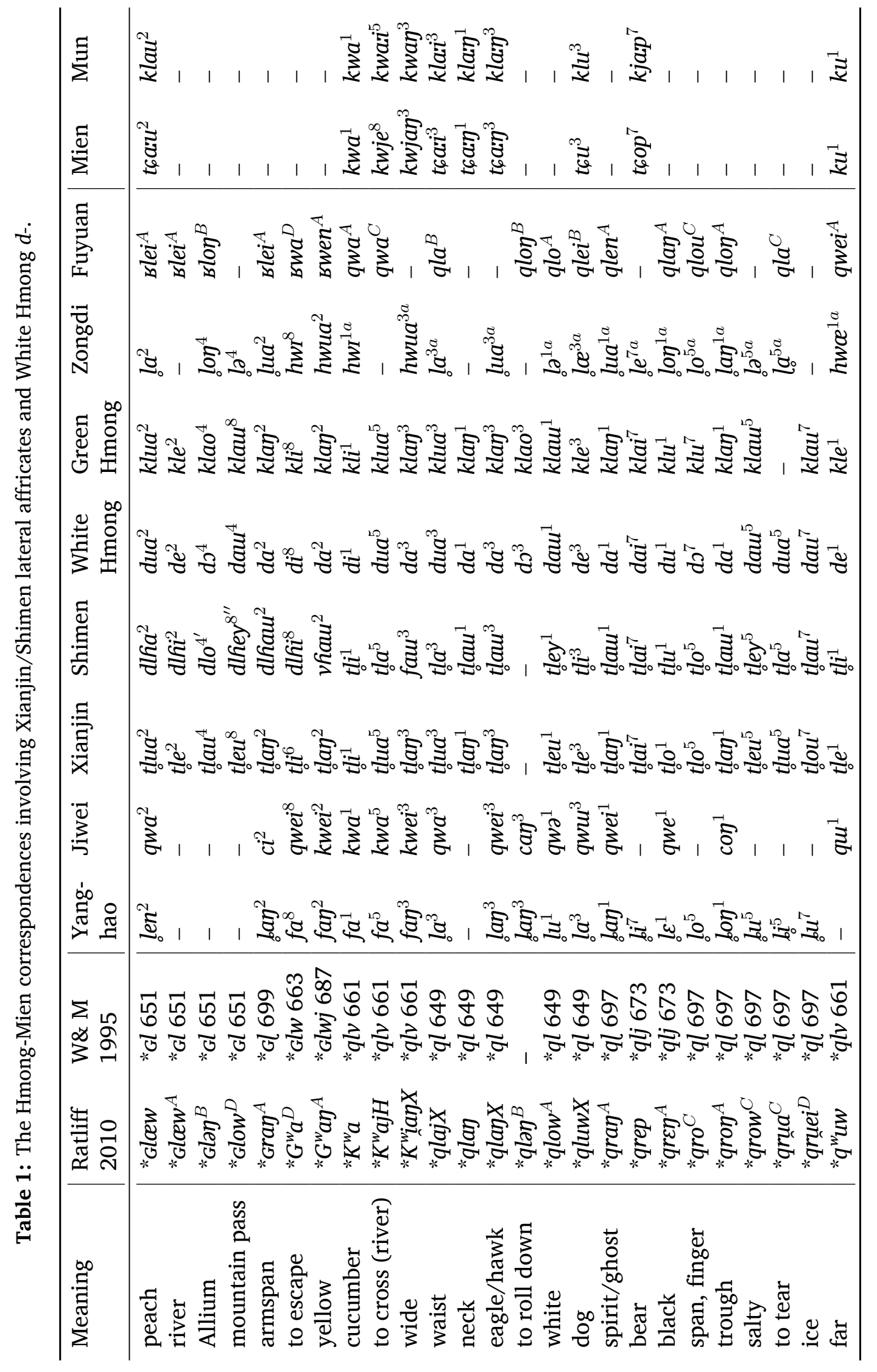


These onsets have two groups of correspondences in other Hmong-Mien languages. First, in the sets labelled \#649, \#651, \#673, \#697 and \#699, the lateral affricates correspond to unvoiced laterals in Yanghao ${ }^{8}$ and Zongdi, ${ }^{9}$ labio-uvulars or $c$ - in Jiwei, ${ }^{10}$ the clusters $b l-$ and $q$ l- in Fuyuan, ${ }^{11}$ and among Mienic languages, $k l$ - in Mun (kimm1245). This group of correspondences is henceforth referred to as 'type I'.

Second, in the sets \#661, \#663 and \#687, they correspond to $f$-in Yanghao, uvular or labiovelars in Jiwei and Fuyuan, $h w$ - in Zongdi, and $k$ - or $k w$ - in Mienic, a group of correspondences which call 'type II' in the following discussion.

The apparent exceptions $v$ hau ${ }^{2}$ 'yellow' (instead of expected $\dagger d l h a u^{2}$ and $\mathrm{fau}^{3}$ 'wide' (instead of †tlaw ${ }^{3}$ 'wide') are treated in section 3.

A similar split is found involving the onset $n t$ - in Xianjin and White Hmong, ndlf- in Shimen and $y g l-$ in Green Hmong. ${ }^{12}$ As shown in Table 2, these onsets can correspond either to [uvular +1 ] clusters or to labiovelars. However, the evidence is more fragmentary, and no convincing cognates in Mienic are found. ${ }^{13}$

Table 2: The Hmong-Mien correspondences involving Xianjin and White Hmong $n t-$ and Shimen and Green Hmong prenasalized lateral affricates.

\begin{tabular}{|c|c|c|c|c|c|c|c|c|c|}
\hline Meaning & $\begin{array}{l}\text { Ratliff } \\
2010\end{array}$ & $\begin{array}{l}\text { Wang \& Mao } \\
1995\end{array}$ & Yanghao & Jiwei & Xianjin & Shimen & $\begin{array}{l}\text { White } \\
\text { Hmong }\end{array}$ & $\begin{array}{l}\text { Green } \\
\text { Hmong }\end{array}$ & Zongdi \\
\hline $\begin{array}{l}\text { front surface } \\
\text { to flow } \\
\text { ragged/shabby }\end{array}$ & 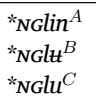 & $\begin{array}{l}\text { *NGl } 654 \\
\text { *NGl } 654 \\
\text { *NGl } 654\end{array}$ & $\begin{array}{l}- \\
- \\
n e i^{6}\end{array}$ & $\begin{array}{l}- \\
- \\
-\end{array}$ & $\begin{array}{l}n t a^{2} \\
n t u^{4} \\
n t u a^{6}\end{array}$ & $\begin{array}{l}\text { ndlfie } e^{2} \\
\text { ndlfyy } \\
\text { ndla }^{4^{\prime \prime}}\end{array}$ & $\begin{array}{l}\text { ntia }{ }^{2} \\
n t u u^{4} \\
n t u a^{6}\end{array}$ & $\begin{array}{l}- \\
\text { yglum }^{4} \\
\text { gglua }^{6}\end{array}$ & $\begin{array}{l}\text { Nqlen }^{A} \\
q^{B} u^{B} \\
q l a^{C}\end{array}$ \\
\hline to have a gap & ${ }^{*} N K^{w} e t$ & ${ }^{*} N q l w 664$ & $q e i^{5}$ & $N q w a^{3}$ & $n t a i^{7}$ & $n$ tlai $^{7}$ & $n t a i^{7}$ & gglai $^{7}$ & - \\
\hline
\end{tabular}

\subsection{Tlowic}

Xianjin tl-, White Hmong $d$ - and Green Hmong $k l$ - correspond to tl- and dlhin Shimen. However, these two onsets are in complementary distribution, the former occurring with high-register tones $(1,3,5,7)$ and the latter with low-register tones $(2,4,6,8)$, while Xianjin tl-, White Hmong $d$ - and Green Hmong $k l$ - occur with both tone registers. The opposition between upper

\footnotetext{
${ }^{8}$ The language of Yanghao village 养蒿寨 (Guizhou) belongs to the Northern Qiandong group (nort2747).

${ }^{9}$ The language of Zongdi 宗地乡, spoken in Yunnan, belongs to the Central Mashan subgroup (cent1394).

${ }^{10}$ The language of Jiwei 吉卫乡 belongs to the Western Xiangxi group (west2430).

${ }^{11}$ The Fuyuan language is spoken in Yejipo village 野鸡坡寨 in Guizhou, and belongs to the Luopohe subgroup (luop1235).

${ }^{12}$ The transcription $y g l-$ in Lyman's Green Hmong dictionary stands for a prenasalized lateral affricate.

${ }^{13}$ Mien $g w a^{7}$ is compared to the etymon of White Hmong $n t a i^{7}$, but it had a final ${ }^{*}-k$ in Mienic (reflected by a glottal stop implied by the tone 7), and this coda should correspond to tone 5 in Hmongic (Downer 1967; Ratliff 2010: 31).
} 
and lower tone register is universally reconstructed as a voicing contrast in proto-Hmongic (Chang 1973; Haudricourt 1951; Niederer 1998; Ratliff 2010; Wang and Mao 1995), and Shimen is thus conservative in preserving onset voicing as a secondary clue of tone register.

It is clear that the White Hmong value $d$ - cannot be the archaic value of these onsets in the common ancestor of these four languages: ProtoHmongic $* d$ - corresponds to $t$ - in low register tone in all Xianjin, White Hmong and Green Hmong, but still voiced in Shimen (for instance 'fire', Xianjin $t e u^{4}$, Shimen dey $^{4^{\prime}}$ and White and Green Hmong tau ${ }^{4}$, Ratliff 2010: 62, Wang and Mao 1995: \#207).

The proto-onsets for the common ancestor of these four languages can be conservatively reconstructed as lateral affricates *tl-/*dl-. ${ }^{14}$ I reconstruct *tl- for high register $t l-, d$ - and $k l$-, and *dl- for low register $t l-, d$-, $k l$ - and $d h l$ - in Shimen, possibly with free variation with *kl- and * $g l$ - as in Green Hmong. White Hmong thus underwent a shift from lateral affricate to preglottalized stop (1), possibly becoming $d$ - in some varieties.

(1) White Hmong delateralization 1

$$
* t l-/ d l-\rightarrow * d
$$

The correspondences in Table 2 can be interpreted as the prenasalized counterparts of the lateral affricates in the common ancestor of these three languages, *ntl- in high-register tones, and *ndl- in low-register. In White Hmong, prenasalization prevented the shift to implosive (1), and prenasalized lateral affricates merged with prenasalized dental stops in White Hmong and Xianjin (the retroflexion in $\eta t u a^{6}$ 'ragged' being unexplained). In Shimen and Green Hmong, the prenasalized lateral affricates did not become delateralized in this context.

(2) White Hmong/Xianjin delateralization 2

*ntl-/ndl- $\rightarrow$ nt- (with devoicing and tonal bipartition)

Whatever the value we want to ascribe to the onsets of type I and type II correspondences (section 2.1) to proto-Hmongic, it is clear that the merger of the proto-onsets of types I and II in Tables 1 and 2 as lateral affricates is a common innovation exclusive to Xianjin, Shimen and White Hmong among the languages treated in Wang and Mao (1995) and Ratliff (2010).

Although this requires further confirmation with additional data, in particular from vocabulary, I provisionally propose that these four varieties constitute a clade within Hmongic, which will be henceforth referred

\footnotetext{
${ }^{14}$ Taking Lyman's transcription of the Green Hmong lateral affricates as [velar +1$]$ clusters, one could alternatively propose $* k l-/{ }^{*} g l-$; this would only marginally change the discussion of the paper.
} 
to as 'Tlowic' following the intermediate reconstruction *tlow ${ }^{A}$ of the etymon 'white' (Xianjin tleu ${ }^{1}$, Shimen tley ${ }^{1}$, White Hmong daw ${ }^{1}$, Green Hmong $k l a w^{1}$, Proto-Hmongic * low $^{A}$ ) in the common ancestor of these four languages (following the sound law $4 \mathrm{~b}$ ). The choice of this etymon to serve a name for the group is because this adjective appears in the self-designation of the White Hmong $h$ mo $^{1}$ daw $^{1}$ (hmoob dawb).

\subsection{Type I correspondence}

There is agreement between Wang and Mao (1995) and Ratliff (2010) on how to reconstruct type I correspondences: all authors posit for these sets a uvular stop ( ${ }^{*} q$ in high-register tone and ${ }^{*} G$ in low-register tone) ${ }^{15}$ followed by a liquid. ${ }^{16}$ The differences in the reconstruction of liquids are minor: * $q / G l$ - are reconstructed in the same words, Wang and Mao's * $q / G l$ and $* q / G l j$ - both correspond to Ratliff $* q / G r$-, the former before non-front vowels, and the latter before front vowels.

The reflexes of these proto-onsets are relatively regular among the languages in the dataset. Jiwei stands out among the languages in having labio-uvulars in most words in type I, and three with $c$ - ( $c i^{2}$ 'armspan', $c a \eta^{3}$ 'roll down' and $\operatorname{co\eta }^{1}$ 'trough'). In view of of the fact that all Hmong-Mien languages other than Jiwei have either [stop + liquid] clusters or onsets obviously originating from such a cluster in this set, it is clear than Jiwei underwent a change from * $q / G l$ - to $q w$-, possibly through a stage with a velar lateral $* q / G t(3 \mathrm{~b})$ following merger of $* r$ and $* l$ after uvular (3a).

All three cases of Jiwei $c$ - correspond to Yanghao $b_{0}$-. Yanghao $b$ - is also found in lay $^{1}$ 'ghost', whose Jiwei reflex is $q w e i^{1}$, but apart from that Jiwei $q w$ - corresponds to Yanghao ${ }_{0}$-. These two languages share a palatalization that is not explainable as secondary development from vowels, and is not reflected in existing reconstructions. Perhaps a palatal glide in protoHmongic can be postulated in these examples (3c), since no clusters * $(q \mid G)(r \mid l) j$ exist in Ratliff's system. ${ }^{17}$

(3) Jiwei delateralization

$$
\text { a. } * q(r \mid l)-/ * G(r \mid l)-\rightarrow * q l-/{ }^{*} G l-
$$

\footnotetext{
${ }^{15}$ Ostapirat (2016) disputes the necessity of reconstructing a contrast between uvulars and velars in proto-Hmong-Mien, and argues that these two series, being in quasicomplementary distribution, have a single origin.

I leave this issue to future research, but in any case it does not substantially change the discussion in this paper - the contrast between velar and uvular has no incidence on the sound changes hypothesized in this work.

${ }^{16}$ In addition to Wang and Mao (1995) and Ratliff (2010), type I correspondences have been discussed by Solnit (1996), who also proposes similar reconstructions.

${ }^{17}$ The amended reconstructions would thus be *Grjay 'armspan', *qljoy 'roll down' and *qrjoy 'trough'. The palatalization in Yanghao la ${ }_{0}^{1}$ 'ghost' is unexplained.
} 
b. *ql-/*Gl- $\rightarrow * q t /{ }^{*} G t \rightarrow q w$ - (with devoicing and tonal bipartition)

c. ${ }^{*} q l j-/{ }^{*} G l j-\rightarrow{ }^{*} q j /{ }^{*} G j \rightarrow c$ - (with devoicing and tonal bipartition)

In Tlowic languages, all [uvular + liquid] clusters merged to lateral affricates *tl-/dl- (4). This change applies to prenasalized clusters (Table 2), and is followed by delateralization in White Hmong (sound laws 1 and 2).

(4) Shift from [uvular + liquid] clusters to lateral affricates in Tlowic
a. ${ }^{*} q(r \mid l)-/{ }^{*} G(r \mid l)-\rightarrow{ }^{*} q l-/{ }^{*} G l-$
b. *ql-/*Gl- $\rightarrow * k l-/ * g l-$
c. $* k l-/ * g l-\rightarrow * t l-/ * d l-$

\section{The interpretation of the type II correspondence group}

\subsection{Tlowic lateral affricates and Chinese labiovelars}

In contrast with the general agreement between Wang \& Mao and Ratliff regarding type I correspondences, the type II group is not easy to reconstruct.

Wang \& Mao reconstruct for this set clusters with *-l- medial (Table 1). However, as pointed out by Ratliff (2010: 125-127), most of the etyma displaying these correspondences have possible Chinese sources, as shown in Table 3 (comprising the four Tlowic languages, and one non-Tlowic language, Fuyuan, for comparison).

Table 3: Type II correspondences as borrowings from Chinese.

\begin{tabular}{|c|c|c|c|c|c|c|}
\hline Meaning & $\begin{array}{l}\text { Chinese } \\
\text { comparison }\end{array}$ & Xianjin & Shimen & $\begin{array}{l}\text { White } \\
\text { Hmong }\end{array}$ & $\begin{array}{l}\text { Green } \\
\text { Hmong }\end{array}$ & Fuyuan \\
\hline \multirow{6}{*}{$\begin{array}{l}\text { escape } \\
\text { yellow } \\
\text { cucumber } \\
\text { to cross (river) } \\
\text { wide } \\
\text { far }\end{array}$} & & $t_{0} i^{6}$ & $d l h i^{8}$ & \multirow{6}{*}{$\begin{array}{l}d i^{8} \\
d a^{2} \\
d i^{1} \\
d u a^{5} \\
d a^{3} \\
d e^{1}\end{array}$} & \multirow{6}{*}{ 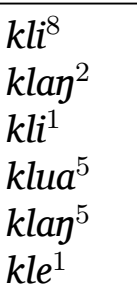 } & \multirow{6}{*}{$\begin{array}{l}{ } \boldsymbol{w} w a^{D} \\
\text { swen }^{A} \\
q w a^{A} \\
q w a^{C} \\
- \\
q w e i^{A}\end{array}$} \\
\hline & 黃 $\gamma w a \eta$ & $t_{0}^{\circ} a \eta^{2}$ & $v f a u u^{2}$ & & & \\
\hline & 瓜 kwae & $t i_{0}^{1}$ & $t l i^{1}$ & & & \\
\hline & 過 kwaH & tlua $a^{5}$ & $t a^{5}$ & & & \\
\hline & 廣 $k w a \eta X$ & tla & $\mathrm{fam}^{3}$ & & & \\
\hline & 迂 $2 j u$ & $t e^{1}$ & $t l i^{1}$ & & & \\
\hline to have a gap & 缺 $k^{h}$ wet & $n t a i^{7}$ & ntlai ${ }^{7}$ & $n t a i^{7}$ & yglai $^{7}$ & - \\
\hline
\end{tabular}

The same correspondence between Middle Chinese $k w$ - and Tlowic * $k l$ - is observed with White Hmong dai ${ }^{5}$ 'hang' (Heimbach 1979), Green Hmong 
$k l a i^{5}$ and Xianjin (Dananshan) $t k a i_{44}^{5}$ (Chen 2012: 880) from 掛 $k w \varepsilon i{ }^{\prime}$ 'hang'. ${ }^{18}$

In Ratliff's hypothesis, the only etymon in this set which is not a Chinese borrowing is 'escape'. Her comparisons are unproblematic, except for 迂 2ju 'twisted, detour', which is semantically and phonetically too different from the Hmong-Mien etymon. ${ }^{19}$ The fact that all of these languages share Chinese borrowings to express these meanings does not imply that borrowing took place at the proto-Hmongic stage: it could be the result of independent borrowing. In particular, the unexpected onsets of $v$ hau ${ }^{2}$ 'yellow' and $\mathrm{fau}^{3}$ 'wide' in Shimen are to be accounted for as recent borrowings (the sound change ${ }^{*} k^{w}-\rightarrow f$ - in 'wide' is identical to that found in Yanghao, where all of these etyma has $f$-, see Table 1 ).

While Middle Chinese lacked consonant clusters, Old Chinese is reconstructed with some $* \mathrm{C}+\mathrm{r}$ - clusters in reconstruction systems based on the ideas of Li (1971), Pulleyblank (1962) and Yakhontov (1963). Among the Chinese etyma in Table 3, medial *-r- is only reconstructed in 瓜 kwee 'cucumber' (reconstructed as " $k^{w} r a$ in Baxter's 1992 system), and with none in all the remaining words (黃 ${ }^{* 1} g^{w} a$, 過 ${ }^{* 1} k^{w} a j s$, 廣 ${ }^{* 1} k^{w} a \eta$ ? and 缺 ${ }^{*} k^{w} e t$ according to Baxter 1992). ${ }^{20}$ All reconstruction systems, including Baxter (1992), Baxter and Sagart (2014), Schuessler (2009) and Starostin (1989) agree on this point, even if they may differ on other issues.

Ratliff's reconstruction of this correspondence implies that the presence of lateral affricates (or sounds originating from lateral affricates by sound laws 1 and 2) is secondary in White Hmong (and other Tlowic languages). ${ }^{21}$

Ratliff's reconstruction of the etyma in table 3 with labiovelars is disputed by Ostapirat (2016: 138; 143), who reconstructs 'cucumber' as ${ }^{*} k l^{y} a^{A}$ 'cross over' as " $k l^{\gamma} a i^{C}$ and 'wide' as ${ }^{*} k l^{\gamma} a \eta^{B}$ in proto-Hmong-Mien with a *-l- based on the evidence from Tlowic languages in Table 3. He also reconstructs velarized onsets rather than labiovelar or labiouvulars like his predecessors. He is aware of the discrepancy between his proto-Hmong-Mien and Old Chinese, and makes a suggestion with far-reaching consequences: "No trace of -1- is found for these words in Chinese, which are usually reconstructed with Old Chinese initial ${ }^{*} k^{w_{-}}$. If they are loans, the borrowing must have gone from MY into Chinese rather than the other way around." (Ostapirat 2016: 143)

The absence of medial in Chinese in these words (in both Middle and Old Chinese) is interpreted by Ostapirat as precluding the possibility of

\footnotetext{
${ }^{18}$ Additional examples may exist, including White Hmong $d a^{5}$, Green Hmong $k l a \eta^{5}$ 'immerse' with 然 $k$ wanH 'wash'.

${ }^{19}$ The initial 影 ?- of Middle Chinese is reconstructed as a uvular * $q^{w}(r) a$ in this word by Baxter and Sagart (2014), following Pan (1997). However, even if the uvular hypothesis is correct, the Hmong-Mien vocalism does not match OC 魚部 *-a.

${ }^{20} \mathrm{~A}$ medial ${ }^{*} r$ - is also reconstructed in the additional example 掛 $k w \varepsilon i H<{ }^{* 1} k^{w} r e ?$.

${ }^{21}$ The sound laws implicitly implied by Ratliff's reconstruction are discussed in section 4.
} 
borrowing from Chinese into Hmong-Mien. ${ }^{22}$

\subsection{The date of borrowing}

Since the words 黃 $\gamma w a \eta$, 過 $k w a H$, 廣 $k w a \eta X$ and 缺 $k^{h} w e t$ are all attested in pre-Han texts, even accepting Ostapirat's hypothesis of borrowing from Hmong-Mien, this borrowing would have had to occur in Old Chinese times. Therefore, Ostapirat's hypothesis could be decisively refuted if we could show that the Tlowic forms are better explained by Middle Chinese than by Old Chinese.

For 'cross', the hypothesis of an Old Chinese borrowing is very likely. We find exactly the same vowel correspondences in all Hmongic languages (including those in Wang and Mao (1995) not included in Table 1) between 'cross' (rhyme \#113 in Wang and Mao) and 'waist' (rhyme \#171), for which the reconstruction *-aj given by Ratliff (2010: 151) is strongly supported by the Mienic cognates (Jiangdi t6ai ${ }^{3}$ ). The reconstruction *-aj for the rhyme of this etymon reflects the final * $*^{-j}$ in the 歌部 *-aj rhyme that is lost in Middle Chinese $-a$ (過 $\left.k w a H<{ }^{* 1} k^{w} a j-s\right) .{ }^{23}$

In the case of 廣 $k w a \eta X$ 'wide', since the Old Chinese form $\left({ }^{* 1} k^{w} a \eta ?\right)$ is similar to its Middle Chinese outcome, little can be said about the age of borrowing.

Concerning Xianjin $t_{o} a \eta^{2}$, White Hmong $d a^{2}$ and Green Hmong $k l a \eta^{2}$ 'yellow', the evidence is ambiguous. The initial 匣 $\gamma w$-in 黃 $\gamma w a \eta$ should yield $v$-in the main layers of borrowings from Middle Chinese. At the same time, 'yellow' is reconstructed in Old Chinese as ${ }^{*} N-k^{w s} a \eta$ with a prenasalized onset by Baxter and Sagart (2014: 81) on the basis of an assumed etymological relationship with 光 kway 'light' and the presence of a trace of prenasalization in the voicing of borrowings of the latter word in Mien (for instance Jiangdi Mien giway ${ }^{1}$ 'light, bright', Mao 1992: 183). If the hypothesis of prenasalization in 'yellow' is accepted, then the Hmong-Mien etymon cannot be borrowed from Old Chinese, otherwise $\dagger n t a^{2}$ would be expected in White Hmong (sound law 2).

The evidence reviewed in this section remains inconclusive: the Hmongic forms of the etymon 'cross' reflect a rhyme correspondence resembling Old Chinese, but the other forms can be interpreted either as Middle or Old Chinese.

\footnotetext{
${ }^{22}$ Ostapirat (2016: 143) uses a similar argument to suggest that Chinese 狗 kuwX< ${ }^{* 1} k(r) o$ ? 'dog' is borrowed from the Hmong-Mien etymon for 'dog', which he reconstructs $* k l u^{B}$ (see the data in Table 1). However, medial *-r-is undetectable before 侯部 *o according to Baxter (1992) and Starostin (1989), so that this argument is vacuous: whether 狗 $k u w X$ is borrowed from the Hmong-Mien 'dog' etymon or not, there is no phonetic evidence to support this hypothesis.

${ }^{23}$ Alternatively, Tlowic - $u a:-a$ : $-u a$ could also come from proto-Hmongic *- $\propto$, but in this case the non-Tlowic languages would have borrowed this etymon separately from Tlowic languages. It is not an impossible hypothesis, but is considerably less parsimonious.
} 
Table 4: Correspondences of 'cross' in Mienic.

\begin{tabular}{|c|c|c|c|c|c|}
\hline Language & $\begin{array}{l}\text { 'waist' } \\
\# 150\end{array}$ & $\begin{array}{l}\text { 'come' } \\
\# 150\end{array}$ & $\begin{array}{l}\text { ‘salty’ } \\
\# 74\end{array}$ & $\begin{array}{l}\text { 'bedbug' } \\
\# 1\end{array}$ & $\begin{array}{l}\text { 'cross' } \\
\# 112\end{array}$ \\
\hline Jiangdi & t6ait ${ }^{3}$ & $\operatorname{tai}^{2}$ & $d z a i^{2}$ & $p j e^{1}$ & $k w j e^{5}$ \\
\hline Xiangjiang & $k a^{3}$ & $t a^{2}$ & $d z a^{2}$ & $p j e^{1}$ & $k j e^{5}$ \\
\hline Luoxiang & $k l a i^{3}$ & $t a i^{2}$ & $d a i^{2}$ & $p i^{1}$ & $k w \partial i^{5^{\prime}}$ \\
\hline Changping & $k l a i^{3}$ & $\operatorname{tai}^{2}$ & $\partial a i^{2}$ & $p i^{1}$ & $k w a i^{5^{\prime}}$ \\
\hline Liangzi & $k l a i^{3}$ & $\operatorname{tai}^{2}$ & $d a i^{2}$ & $p i^{1}$ & $k w i^{5}$ \\
\hline Lanjin & $k l a i^{3}$ & $\operatorname{tai}^{2}$ & $d a i^{2}$ & $p i^{1}$ & $k w a i^{5}$ \\
\hline Dongshan & $k l a^{3}$ & $t a^{2}$ & $d z a^{2}$ & $p i^{1}$ & $k w a^{5}$ \\
\hline Sanjiang & $l a i^{3}$ & - & $t s w e i^{2}$ & beg $\eta^{1}$ & $k w e i^{5}$ \\
\hline Daping & $l a i^{3}$ & $t \varepsilon i^{2}$ & $d i^{2}$ & $b \varepsilon i^{1}$ & $k \varepsilon i^{5}$ \\
\hline
\end{tabular}

\subsection{Phylogeny and the interpretation of the correspondences}

The decisive evidence against Ostapirat's hypothesis does not come from the dating of the Chinese borrowings, but rather from the correspondences with Mien.

The etymon 'cross' is also found in Mienic, where it presents a unique set of correspondences, listed in Table 4, with a comparison with other etyma to provide the expected outcomes of the proto-Hmong-Mien rhymes *-aj and *-ji discussed below.

Among these forms, Jiangdi, Xiangjiang, Liangzi and Daping have correspondences compatible with an alternative reconstruction *kwji in Ratliff's system (same as 'bedbug'). It is possible that these languages represent a different etymon unrelated to the Chinese word, but superficially similar. ${ }^{24}$ Among the other languages, Lanjin and Dongshan have the rhyme expected for a proto-form *kwajX lautgesetzlich comparable with the Tlowic forms in Table 3, and the rhyme -ei in Sanjiang corresponding to -ai in Lanjin is attested in a few other words. The remaining languages have rhymes coming either from *-oj (Luoxiang) or *-aj (Changping). Thus, excluding Jiangdi, Xiangjiang, Changping (and possibly Daping), whose etymon for 'cross' may be a native etymon only superficially resembling Chinese ${ }^{25}$ the remaining Mienic languages have a rhyme with an open or mid-open vowel followed by a coda ${ }^{*}-j$.

The presence of this coda indicates that these forms are comparable to

\footnotetext{
${ }^{24}$ Alternatively, Jiangdi and Xiangjiang could go back to a proto-form ${ }^{*} k^{w} j a H$, with the same treatment of *-jwa as in Jiangdi jwe 'urine'. However, such a solution would create more problems than it solves: it leaves the Liangzi form isolated, and neither Middle nor Old Chinese are not compatible with the $-j$-. Even accepting Ostapirat's hypothesis, $-j$ - could not be the trace of a liquid medial *-r- or *-l-, otherwise $t \varphi$ - would be expected in Jiangdi.

${ }^{25}$ Labiovelars are found in a certain number of Mienic native etyma, for instance $* g^{w} j a X$ 'get up' (Jiangdi kwje ${ }^{4}$ ).
} 
Old Chinese rather than to Middle Chinese, but while some may be inherited from proto-Hmong-Mien and cognate with the Hmongic etymon, the Luoxiang and Changping form must reflect independent borrowing. ${ }^{26}$

Not all Mienic languages preserve medial liquids faithfully. Some such as Jiangdi lost them, some such as Lanjin only preserves *-l-, but Sanjiang still keeps a trace of ${ }^{*}-r$ - (for instance $k_{l j k}{ }^{7}$ 'bear' from *qrep, see table 1 ). Even in the Mienic languages that lose the medials, they merged with $-j$ and thus did not vanish without trace.

Thus, Ostapirat's hypothesis that the laterals in the etyma in Table 3 should be reconstructed to proto-Hmong-Mien raises not only a problem for the comparison of Hmongic with Chinese, but also for Hmong-Mien reconstruction. While few works have been published on the Stammbaum of the family, it is clear that Tlowic is not the first clade to branch off of Hmong-Mien or even Hmongic, and that the first branching of the family is between Hmongic and Mienic. Within Hmongic, Baheng, She and Jiongnai are generally considered to be the outgroups (Ratliff 2010: 3).

Ostapirat's hypothesis postulates the existence of a third medial liquid distinct from *-l- and *-r-, only reflected in Tlowic, and independently merging with *-w-more than three times: in the passage to Chinese, in Mienic and in the Hmongic outgroups.

In addition to the lack of plausibility regarding the direction of borrowing, this hypothesis is highly non-parsimonious, and cannot be accepted unless independent evidence of a medial liquid in these words is found in an independent source of data. Therefore, Ratliff's hypothesis of a shift from labiovelar to lateral affricates is the preferable option.

\section{Consequences for Hmongic historical phonology}

\subsection{Lateralization of labiodorsals}

The only weakness of Ratliff's hypothesis is the apparent phonetic difficulty of deriving lateral affricates from labiovelars or labiouvulars. In particular, despite the presence of a series of labiovelars in proto-Indo-European, Kümmel (2007: 146; 255) ${ }^{27}$ does not document any sound change of this type in the sections on Lateralisierung and Entlabialisierung.

\footnotetext{
${ }^{26}$ This verb has been highly successfully borrowed in many different languages, including Kra-Dai (Pittayaporn 2009: 352), though Old Chinese borrowings are only found in HmongMien as far as I know. Since the forms of 'cross' in Kra-Dai reflect Middle Chinese, they are not relevant to the present discussion.

${ }^{27}$ While there are are several detailed surveys of synchronic phonological system ( Gordon 2016; Maddieson 1984; Moran and McCloy 2019; Nikolaev 2018), global databases on sound changes and their directionality (Ben Hamed and Flavier 2009) are still under construction, so that Kümmel (2007), despite its limitation to three language families, remains the largest sourcebook for diachronic phonological typology.
} 
However, the hypothesis of a shift from labio-dorsals to lateral affricates is not in fact so outlandish as it may appear at first sight. Rather than a single sound change, it can be accounted for by positing two steps: the labial articulation develops a lateral articulation and shifts to * $t$ in this context (5a), followed by merger between ${ }^{*} q t /{ }^{*} G t$ and $* q l /{ }^{*} G l$ to the latter $(5 b) .{ }^{28}$

$$
\begin{aligned}
& \text { a. }{ }^{*} q w-/{ }^{*} G w-\rightarrow{ }^{*} q t /{ }^{*} G t \\
& \text { b. } \left.* q t /{ }^{*} G t \rightarrow * q l /{ }^{*} G l \text { (merger of } * t \text { and } * l\right)
\end{aligned}
$$

In addition, (5b) feeds the change of [uvular + liquid] clusters to lateral affricates in Tlowic languages (4b).

The hypothetical shift (5) is the converse of the Jiwei lateral to labial glide shift (3b) discussed above. The only apparent difficulty is to assume that the direction of the shift from a lateral to a labial glide can be bidirectional. While this idea may seem counterintuitive, at least one example of change from labial glide to a liquid is attested: proto-Algonquian * $w$ merges with $* y,{ }^{*}{ }^{29}$ and $* n$ to $n$ (except in word-internal clusters, Goddard 1974: 106). These correspondences can be explained by a series of mergers ${ }^{*} w>*^{*}>*^{*} /{ }^{*} l>{ }^{*} n$ (Jacques 2013: 51; 54), involving thus a change from ${ }^{*} w$ to $* r$ or $* l$ in two steps.

Even though the shift from labial glide to liquid in Arapaho is different in particular details from the sound change (5a) hypothesized for Tlowic, at least it disproves the idea that sound changes involving labial glides and laterals are necessarily unidirectional. ${ }^{30}$

\subsection{Further implications of the lateralization rule}

The shift (5), if accepted, has several important implications for Hmongic historical phonology and the comparison of Tlowic data to other languages.

First, due to the merger of labio-dorsals with [uvular + liquid] clusters in Tlowic, the existence of an onset originating from a velar + lateral cluster ( $* k l-, " * g l-$ and their prenasalized counterparts, White Hmong $d$ - and $n t-$ ) cannot be used to prove the existence of a liquid medial in proto-Hmongic without confirming data from a Hmongic language that has not undergone merger between the two types of onsets (ie, any Hmongic language other than Tlowic and Jiwei).

Second, the lateral in Tlowic languages cannot be used as evidence to support Yakhontov's *-r- medial hypothesis in the borrowings dai ${ }^{5}$ 'hang'

\footnotetext{
${ }^{28} \mathrm{~A}$ typological parallel of this merger is the so-called bylaczenie in northeastern Kashubian (Toby 2000: 331).

${ }^{29}$ There was no contrast between laterals and rhotics in proto-Algonquian, and the phoneme reconstructed here as * $r$ is noted * $l$ by Bloomfield (1925).

${ }^{30}$ Unlike for instance the case of fricative debuccalisation, where a strong case for unidirectionality can be made (Ferguson 1990).
} 
(Chinese 掛 $k w \varepsilon i H<{ }^{* 1} k^{w} r e$ ) ) and $d i^{1}$ 'cucumber' (Chinese 瓜 $k w c e<{ }^{1} k^{w} r a$ ), and even less to reconstruct laterals in first division words like $d u a^{5}$ 'cross' (過 $k w a H<{ }^{* 1} k^{w} a j-s$ ), contra Ostapirat (2016) and scholars who approvingly use his reconstructions (Akitani 2017: 42; Smith 2021).

Third, etyma presenting type II correspondence cannot be compared to etyma with lateral onsets in Chinese or other languages. For instance, the etymon 'escape' (Xianjin $t i_{o}^{6}$, Shimen $d l h i^{8}$, White Hmong $d i^{8}$, Green Hmong $k l i^{8}$ ) is not comparable to either 脫 $d w a t<{ }^{* 1}$ lot (Sagart 1999: 123) or to the cognates of this etymon in non-Sinitic Trans-Himalayan languages as proposed by Mortensen (2002) in view of forms such as Fuyuan $s w a^{D}$ (Table 1) which imply a proto-Hmongic labiovelar.

\section{Conclusion}

The present paper has three main contributions, concerning Hmong-Mien, Chinese and panchronic linguistics.

First, it lays out in detail five sound changes in several Hmongic languages, and it documents the highly unusual shift from labio-dorsal to lateral affricates (resulting from the combination of 5 and 4), apparently not attested elsewhere, and thus contributing to the typology of sound changes.

Second, it provides evidence from exclusive phonetic innovations for a 'Tlowic' subgroup within Hmongic comprising White Hmong, Green Hmong, Xianjin (Dananshan, Chuanqiandian) and Shimen.

Third, it disproves the idea that the lateral affricates in Tlowic corresponding to labiovelars in Chinese and elsewhere are archaisms, and that these data could be used to revise Old Chinese reconstructions.

\section{Acknowledgments}

I would like to thank Martha Ratliff and two anonymous reviewers for useful comments on previous versions of this work.

\section{References}

Akitani, Hiroyuki. 2017. Mǐn běiqū fāngyán de yīndiào zhuóshēngmǔ zì de kăochá - - jiānpíng Bái - Shā shànggǔ xīn xìtǒng 閩北區方言的陰調濁 聲母字的考察——兼評白 - 沙上古新系統 [A study of the historical upper register voiced onset wordsof the Northern Min dialects, with remarks on the new Old Chinese system of Baxter \& Sagart]. Yǔyánxué lùncóng 语 言学论丛 56. 20-75. 
Baxter, William H. III. 1992. A Handbook of Old Chinese Phonology. Berlin: Mouton de Gruyter.

Baxter, William H. \& Laurent Sagart. 2014. Old Chinese: A new reconstruction. Oxford: Oxford University Press.

Ben Hamed, Mahé \& Sébastien Flavier. 2009. UNIDIA: A database for deriving Diachronic Universals. In Etleva Vocaj, Fernande Dupuis \& Monique Dufresnes (eds.), Historical Linguistics 2007: Selected papers from the 18th International Conference on Historical Linguistics, Montreal, 6-11 August 2007, 259-268. Amsterdam: John Benjamins.

Bloomfield, Leonard. 1925. On the sound-system of Central Algonquian. Language 1(4). 130-156.

Chang, Kun. 1973. The reconstruction of proto-Miao-Yao tones. Bulletin of the Institute of History and Philology 44(4). 541-628.

Chappell, Hilary \& Alain Peyraube. 2015. The comparative construction in Sinitic languages: Synchronic and diachronic variation. In Hilary Chappell (ed.), Diversity in Sinitic languages, 134-154. Oxford: Oxford University Press.

Chen, Qiguang. 2012. Miáoyáo yǔwén 苗瑶语文 [Miao-yao languages and scripts]. Beijing: Zhongyang minzu daxue chubanshe.

Chiang, Min-hua. 2017. Kèjiāhuà de chābǐjù jí xiāngguān wèntí 客家話 的差比句及相關問題 [The comparison of inequality in hakka and some related issues]. Cahiers de linguistique - Asie orientale 46(2). 121-150.

Downer, Gordon B. 1967. Tone-change and tone-shift in White Miao. Bulletin of the School of Oriental and African Studies 30(3). 589-599.

Ferguson, Charles A. 1990. From esses to aitches identifying pathways of diachronic change. In William A. Croft, Suzanne Kemmer \& Keith Denning (eds.), Studies in typology and diachrony: Papers presented to Joseph H. Greenberg on his 75th birthday, 59-78. Amsterdam: Benjamins.

Goddard, Ives. 1974. An Outline of the Historical Phonology of Arapaho and Atsina. International Journal of American Linguistics 40(2). 102-116.

Gordon, Matthew K. 2016. Phonological typology. Oxford: Oxford University Press.

Hammarström, Harald, Robert Forkel, Martin Haspelmath \& Sebastian Bank. 2020. Glottolog 4.3. Jena. doi:10.5281/zenodo.4061162. https: //glottolog.org/, accessed 2020-11-27. 
Haudricourt, André-Georges. 1951. Introduction à la phonologie historique des langues miao-yao. Bulletin de l'Ecole française d'Extrême-Orient 44(2). 555-576. https://www.persee.fr/doc/befeo_0336-1519_1951_num_ 44_2_5185, accessed 2020-11-27.

Heimbach, Ernest E. 1979. White Hmong-English dictionary. Ithaca: Cornell University Southeast Asia Program, Department of Asian Studies.

Jacques, Guillaume. 2013. The sound change *s $>\mathrm{n}$ in Arapaho. Folia Linguistica Historica 34(1). 43-58.

Jarkey, Nerida. 1987. An investigation of two alveolar stop consonants in White Hmong. Linguistics of the Tibeto Burman Area 10. 57-70.

Kümmel, Martin J. 2007. Konsonantenwandel: Bausteine zu einer Typologie des Lautwandels und ihre Konsequenzen fur die vergleichende Rekonstruktion. Wiesbaden: Dr. Ludwig Reichert Verlag.

Li, Fang-Kuei. 1971. Shànggǔyinn yánjiū 上古音研究 [Studies on Archaic Chinese]. The Tsing Hua Journal of Chinese Studies 9(1,2). 1-61.

Lyman, Thomas Amis. 1974. Dictionary of Mong Njua. The Hague: Mouton.

Maddieson, Ian. 1984. Patterns of sounds. Cambridge: Cambridge University Press.

Mao, Zongwu. 1992. Hàn-Yáo cídiăn (miǎnyǔ) 汉瑶词典（勉语） [A Chinese-Mien dictionary]. Chengdu: Sichuan minzu chubanshe.

Moran, Steven and Daniel McCloy (eds.). 2019. PHOIBLE 2.0. Jena: Max Planck Institute for the Science of Human History. http: //phoible org, accessed 2020-11-27.

Mortensen, David. 2002. A preliminary survey of Tibeto-Burman loanwords in Hmong-Mien languages. Paper presented at the 37th conference on Sino-Tibetan Languages and Linguistics.

Mortensen, David. 2004. Preliminaries to Mong Leng (Hmong Njua) phonology. Unpublished manuscript, University of California, Berkeley.

Niederer, Barbara. 1998. Les langues Hmong-Mien (Miao-Yao), Phonologie historique. München: Lincom.

Nikolaev, Dmitry. 2018. The database of eurasian phonological inventories: A research tool for distributional phonological typology. Linguistics Vanguard (1). 20170050. doi:10.1515/lingvan-2017-0050, accessed 2020-11-27. 
Ostapirat, Weera. 2016. Issues in the reconstruction and affiliation of ProtoMiao-Yao. Language and Linguistics 17(1). 133-145.

Pan, Wuyun. 1997. Houyin kao 喉音考 [On uvulars in Old Chinese]. Mínzú yǔwén 民族语文 10-24.

Pittayaporn, Pittayawat. 2009. The Phonology of proto-Tai. Cornell University Dissertation.

Pulleyblank, Edwin G. 1962. The consonantal system of Old Chinese. Asia Major 9(1-2). 58-144; 206-265.

Ratliff, Martha. 2010. Hmong-Mien language history. Canberra: Pacific Linguistics.

Sagart, Laurent. 1999. The roots of Old Chinese. Amsterdam and Philadelphia: Benjamins.

Schuessler, Axel. 2009. Minimal Old Chinese and Later Han Chinese: A Companion to Grammata Serica Recensa. Honolulu: University of Hawai'i Press.

Smith, Jonathan M. 2021. Diverse sources and an internal foundation for voiced onsets in northern Mǐn. Language and Linguistics 22(1). 71-110.

Solnit, David B. 1996. Some evidence from biao min on the initials of proto-mienic (yao) and proto-hmong-mien (miao-yao). Linguistics of the Tibeto-Burman Area 19(1). 1-18.

Starostin, Sergej Anatoljevich. 1989. Реконструкция древнекитайской фонологической системы [A reconstruction of the Old Chinese phonological system]. Moskva: Nauka.

Toby, Hanna. 2000. On the low german influence on kashubian dialects. Studies in Slavic and General Linguistics 28. 329-334.

Wang, Fushi and Zongwu Mao. 1995. Miáoyáoyǔ gǔyin gòuň̌ 苗瑶语古音 构拟 [A reconstruction of proto-Miao-Yao]. Beijing: Zhongguo shehui kexue chubanshe.

Yakhontov, Sergei Ye. 1963. Сочетания согласных в древнекитайском языке. [Consonant clusters in Old Chinese] In Tpyды XXV Международного конгресса востоковедов, 89-95. 